Chapter Title: Shanzhai $=$ Creativity, Creativity $=$ Shanzhai

Chapter Author(s): Stefan Landsberger

Book Title: Boredom, Shanzhai, and Digitisation in the Time of Creative China

Book Editor(s): Jeroen de Kloet, Chow Yiu Fai, Lena Scheen

Published by: Amsterdam University Press. (2019)

Stable URL: https://www.jstor.org/stable/j.ctvqr1bnw.17

JSTOR is a not-for-profit service that helps scholars, researchers, and students discover, use, and build upon a wide range of content in a trusted digital archive. We use information technology and tools to increase productivity and facilitate new forms of scholarship. For more information about JSTOR, please contact support@jstor.org.

Your use of the JSTOR archive indicates your acceptance of the Terms \& Conditions of Use, available at https://about.jstor.org/terms

This book is licensed under a Creative Commons Attribution-NonCommercialNoDerivatives 4.0 International License (CC BY-NC-ND 4.0). To view a copy of this license, visit https://creativecommons.org/licenses/by-nc-nd/4.0/. access to Boredom, Shanzhai, and Digitisation in the Time of Creative China 


\title{
2.5 Shanzhai = Creativity, \\ Creativity = Shanzhai
}

\author{
Stefan Landsberger
}

\begin{abstract}
Shanzhai has come to refer to all Chinese counterfeit products and to the attitude of their producers towards authority. One argument that explains the popularity of shanzhai products in China is that the average consumer could not afford original name brands, and that by acquiring a cheaper version, one could find out whether it was worthwhile to own an original. While shanzhai has turned into a phrase and concept that many in the West are familiar with, many Chinese are not, or no longer; most do not care whether the goods they consume are 'authentic' or not. Other Chinese are embarrassed by the frequent use of the concept in combination with the signifier 'China'.
\end{abstract}

Keywords: Shanzhai-as-mimicry, counterfeit, authenticity, Dafen Oil Painting Village, Dark shanzhai

Literally, Shanzhai refers to the mountain stronghold defended by fiercely patriotic freedom fighters à la Robin Hood, resisting the authoritarian imperial rule of the Song Dynasty and supporting the poor and the weak. The image has been around for a long time in China. Shi Nai'ans popular novel Water Margin, which was first published in 1589, had made the rebels, as well as their stronghold in the Liangshan Marshes, household names in China. Non-Chinese readers had to wait until the 1930s to get to know these guerrillas and learn of their exploits, when Pearl Buck's masterful translation All Men are Brothers (1933) appeared. ${ }^{9}$ Over time, shanzhai came to refer to all counterfeit products and to the attitude of their producers towards authority. After China's accession to the World Trade Organization in 2001, the flood of goods coming out of China that had already started to

9 Fan Yang, 'From Bandit Cell Phones to Branding the Nation: Three Moments of Shanzhai in WTO-era China', Positions: East sia cultures critique 24.3 (2016): 590; William Hennessey, 'Deconstructing Shanzhai - China's Copycat Counterculture: Catch Me If You Can', Campbell Law Review 34.6og (2012): 614-616. 
make inroads in the 1980s, increased exponentially. By 2008, the 'year of shanzhai' as the internet site Renmin wang (People's Net) named it, ${ }^{1}$ when China monopolised the global gaze through the Olympics, the Wenchuan Earthquake, the riots in Tibet and Xinjiang, the Sanlu Milk Powder Scandal, and its first space mission, shanzhai had become the moniker, both inside China and without, for cheap imitation products, copycat wares. China came to be seen as the bootlegging capital of the world. ${ }^{2}$

\section{Is Shanzhai ‘Typically’ Chinese?}

Much has been theorised about the origins of shanzhai-as-mimicry, as counterfeit, often pointing to the differences in appreciating creativity (and originality) that are said to exist between China and the West (or the rest). The Chinese traditionally valued technical expertise as expressed in immaculate workmanship, attained by endlessly copying a flawless original created by an acknowledged master. In other words, the ability to masterfully copy was seen as proof of a creator's artistic value. The quality of the final product mattered more than whether it was an original piece of work or not. As Fan Feng argues in this volume, the West, for example the Delft Blue pottery producers in Holland, shanzhaied original Chinese craftsmanship. This indicates that copying is not necessarily an activity that can be monopolised by a single people or nation but is part of a wider developmental process. ${ }^{3}$ On a more contemporary note, Xiao Yuefan demonstrates in this volume how the roots of the practice of shanzhai actually could be traced back to important discursive elements in Mao Zedong Thought (i.e. the concepts of art for the people and the Mass Line and the principle of self-reliance) that were translated into practice in such mass movements as the Great Leap Forward. On the basis of such arguments, copying has been defended as an inherent trait of Chinese culture, and shanzhai production as something to be fiercely proud of.

$1 \quad$ Yang, 'From Bandit Cell Phones to Branding the Nation', 589.

2 Lai-kwan Pang, 'China Who Makes and Fakes - A Semiotics of the Counterfeit', Theory, Culture \& Society 25.6 (2008): 120.

3 Ibid., 123,

Kloet, Jeroen de, Chow Yiu Fai, and Lena Scheen (eds), Boredom, Shanzhai, and Digitisation in the Time of Creative China. Amsterdam, Amsterdam University Press 2019 DOI: $10.5117 / 9789462984745 \_$CH2.5 
But shanzhai was - and is - more than just industrial-scale counterfeiting and piracy; it consists of 'parodies, irreverent protests, and "grassroots innovations" that exploit "the ambiguities" and skirt the rules rather than break them. ${ }^{4}$ This precisely puts a fine point on the different ways of interpreting shanzhai: many non-Chinese see shanzhai products merely (and only) as 'simply low-priced counterfeits of well-known brands', ${ }^{5}$ completely missing the playfulness that is part and parcel of the process. Equating shanzhai with counterfeit also turns a blind eye to the elements of adopting global goods, grass-roots participation, and resistance against authority that are bound in the original meaning of the term.

\section{Shanzhai as Emblem of Development and Modernity}

The term shanzhai as it emerged in the 2000 s initially was very much associated with cheap mobile phones, often produced by small, semi-legal workshops, many of them family-run, which imitated established (foreign) brands. These producers made use of the opportunities provided by access to (more) advanced technology from elsewhere, the opportunity to run private businesses and sheer entrepreneurship. Their phones first emerged in Southeast China's Pearl River Delta, comprising Guangzhou, Hong Kong, and the adjacent bubble-city of Shenzhen, the region that became the crucible of the reform and development frenzy that has propelled China forward. The qualities these phones offered were multiple; they were cheap, for sure, and this allowed many, often with little money in their pockets, to join the wonderful world of mobile communications. It is no wonder that the largest initial group of users could be found among the migrant workers who had moved from the countryside to the cities, providing the cheap fuel and lubricants, as it were, for the Chinese economic machine. ${ }^{6}$ At the same time, they conferred status on their users, not only because they looked almost exactly like the much more expensive originals that they copied,7 but because they allowed access to advanced modes of communications. Moreover, they often could boast of functions that the originals did not

4 Hennessey, 'Deconstructing Shanzhai', 660-61.

5 Yiying Wu and Jack Whalen, Portraits of Chinese Shanzhai (New York: American Sociological Association Annual Meeting 2013).

6 Carolyn Cartier, Manuel Castells, and Lin-chuan Qiu, 'The Information Have-Less: Inequality, Mobility, and Translocal Networks in Chinese Cities', Studies in Comparative International Development 40.2 (2005): 11; Yang, 'China's “Fake” Apple Store: Branded Space, Intellectual Property and the Global Culture Industry', Theory, Culture \& Society 31.4 (2014): 83-84.

7 Wu and Whalen, Portraits of Chinese Shanzhai. 
have (yet) and increasingly, they came with a quirk. Just think of the mobile phone unit with a Rolex Oyster watch plate attached to it, combining two symbols of taste, refinement and wealth into one invincible statement of status. I personally find the packet-of-Panda-cigarettes-phone one of the greatest inventions ever; all the more so because Panda cigarettes were the favourite brand of Deng Xiaoping, the 'Chief Architect' of China's reform and opening up. This particular phone thus not only let its users have the vicarious pleasure of owning a pack of Panda cigarettes, but at the same time supported and/or paid homage to the leader who had made owning a mobile phone possible in the first place.

As more companies came in contact with foreign products and companies for which they started to assemble semi-finished products in the 1990s, the menu of shanzhai products grew. As Chubb writes, '[f]rom shanzhai mobile phones to shanzhai superstars, from shanzhai news to shanzhai police stations, from shanzhai cigarettes to shanzhai trains, for a time it seemed that nothing could not be shanzhaied in China'. ${ }^{8}$ It needs further research to ascertain whether the Adidos or Dasabi brand running shoes on offer were thus named on purpose, to evade copyright issues; to hoodwink customers who are unaware of the difference; or with an ironic wink to the more knowledgeable consumer. In the same vein, does the customer wearing clothes from the Dolce \& Banana brand know they are the real deal or not? Does a cup of Starfucks coffee give the same satisfaction as its (almost) namesake? And does it really matter? One argument explaining the popularity of shanzhai products frequently heard in China in the 1990s and early 20oos was that original brands were out of reach for the average Chinese consumer, and that by acquiring a cheaper version of them, $\mathrm{s} / \mathrm{he}$ would be able to find out whether it was worthwhile to aspire to owning an original in the future or not.

\section{The Legality of Shanzhai}

Increasingly, however, copyright holders started to make noises about missing out on their royalties. As long as these companies were located outside of China, and had deep pockets, the Chinese authorities did not really seem to care. Yes, of course, it could be heard in official quarters, China was a nation one can depend on; of course, China observed its legal obligations; of course, copyright was something sacred in China too; certainly, China

8 Andrew Chubb, 'China's Shanzhai Culture: “Grabism” and the politics of hybridity', Journal of Contemporary China 24.92 (2015): 261. 
would do its utmost to apprehend and punish the perpetrators. The problem was that ' $S]$ hanzhai behaviour is not necessarily against the law; it is just outside of the government's control'.9 This applied all the more when the shanzhaiing companies in question operated under the actual and active protection of state agencies. It is worth noting that as soon as Chinese companies discovered that their own products came to be 'shanzhaied' by local companies in more remote inland areas, a considerable amount of official effort could be freed to try and bring these practices under control, thereby also benefitting the foreign companies that had been complaining about the practice all along. In the process, the finer ins-and-outs of copyrights and their protection became better understood.

While this process took form, many of the small companies that originally had started out as shanzhai producers attained respectability, evolving into legitimate businesses that took on established global brands on the basis of original new products, often in completely different fields from where they had started. The BYD Company (Build Your Dreams) is a good example of this process. It started out producing rechargeable batteries for mobile phones, competing with and potentially making use of (i.e. shanzhaiing technology developed by) Japanese companies, which monopolised the Chinese market. After 2002, it branched out into automobile research and development, becoming one of the big electric and gas-powered auto makers in China. In a way, something similar has happened in respect to the Dafen Oil Painting Village. First, it was merely a place where painters worked, copying established masterpieces, initially for the European and American markets, later also for the domestic one. It attracted curious foreign journalists, who wrote humorous media reports about fake Van Gogh's. Then, it became an example of a village-based cultural industry that merited emulation elsewhere in China, as can be seen from the fact that it was presented as the main theme of the Shenzhen Pavilion in the Best Urban Practices Zone during the Shanghai Expo in 2010. ${ }^{10}$ Now it has become a Gesamtwerk: it is like a huge studio where art is recreated in various small workshops by professionals, and at the same time a tourist village providing the spectacle of an art-copying village in full operation. The Dafen Art Museum attributes legitimacy to the art works produced within the city boundaries by exhibiting them for what they are: works of art. Questions about their authenticity or originality are neither raised, nor answered.

9 Hennessey, 'Deconstructing Shanzhai', 661.

10 Si-ming Li, Hung-ha Cheng, and Jun Wang, 'Making a Cultural Cluster in China: A study of Dafen Oil Painting Village, Shenzhen', Habitat International 41 (2014): 156, 158-16o. 


\section{Dark Shanzhai}

Let us not forget that there also is a dark side to what most consider the playfulness of shanzhai. I am thinking specifically of the counterfeit goods that are not produced with the intention of selling them cheaply, but to fool the end users into believing they are buying original products and thereby make a fortune. Those falling victim of these practices often tend to be people from the (remote) countryside who lack the savviness of urbanites. ${ }^{11}$ Both inside China and outside, cases have been reported about the sales of fake (but expensive) medical drugs; about baby formula made of nothing but chalk; about spare parts used in the aviation and other industries that have not properly gone through quality control regimes, etc. With the lives of innocent people at stake, these cheap production processes only seem to benefit producers without qualms or conscience.

Yet, shanzhai as such seems to have become a non-brand, a 'not-good' product because it has no recognisable brand name. ${ }^{12}$ It is interesting to note that while shanzhai has turned into a phrase and concept that many in the West are familiar with, many Chinese are not or no longer; or they do not care about the goods they consume being 'authentic' or not. Other Chinese are embarrassed by the frequent use of the word/concept in direct combination with the word 'China'. At the same time, however, as the mood of the nation has taken on a more patriotic hue from the 1990s onwards, more and more people consider buying shanzhai, i.e. locally produced goods rather than (expensive) imported ones, as a way of showing that they not only 'love the nation' but actively support its industries, thus expressing a form of consumer nationalism while at the same time being able to enjoy and take part in the pleasures of global consuming. ${ }^{13}$ As times have passed, the clear distinctions between real and not, between foreign-produced and indigenous increasingly have become blurred. For many of the post-gos generation and beyond, the so-called millennials, the question of buying (into) shanzhai is no longer relevant. They have developed their own playfulness, their own way of mixing-and-mashing-up, and their own behavioural and sartorial codes.

11 Wu and Whalen, Portraits of Chinese Shanzhai.

12 Ibid.

13 Lu-wang Cheng and Zhen Xiong Chen, 'Consumer Ethnocentrism and Willingness to Buy Domestic Products in a Developing Country Setting: Testing Moderating Effects', Journal of Consumer Marketing 21.6 (2004): 393-394. 


\section{In Closing}

Given that shanzhai is not branded, why is it that until the present, no clever businessperson or marketer has registered a copyright for the term (or the practice of) shanzhai? It surely is a great brand name with global recognition. As a brand, it offers wonderful opportunities to produce goods (or services) of whatever stripe, although not necessarily with the same tongue-in-cheek qualities that some Chinese shanzhai products (have) had. I find it odd that the Chinese entrepreneurial spirit, the ethos of which is personified in Alibaba founder Jack Ma Yun, who is praised and worshipped on an almost daily basis both within and without China, has had a blind spot for this. So, let's use shanzhai as a rallying cry to turn 'China the Pirate; Chinese, the Uncreative' into their opposites! To make it the brand that signifies the turn from 'made in China' to 'created by China'!

\section{Bibliography}

Cartier, Carolyn, Manuel Castells, and Lin-chuan Qiu. 'The Information Have-Less: Inequality, Mobility, and Translocal Networks in Chinese Cities', Studies in Comparative International Development 40.2 (2005): 9-34.

Cheng, Lu-wang, and Zhen Xiong Chen. 'Consumer Ethnocentrism and Willingness to Buy Domestic Products in a Developing Country Setting: Testing Moderating Effects', Journal of Consumer Marketing 21.6 (2004): 391-400.

Chubb, Andrew. 'China's Shanzhai Culture: “Grabism” and the Politics of Hybridity', Journal of Contemporary China 24.92 (2015): 260-279.

Hennessey, William. 'Deconstructing Shanzhai-China's Copycat Counterculture: Catch Me If You Can', Campbell Law Review 34.6og (2012): 6o9-661.

Li, Si-ming, Hung-ha Cheng, and Jun Wang. 'Making a Cultural Cluster in China: A Study of Dafen Oil Painting Village, Shenzhen', Habitat International 41 (2014): 156-164.

Pang, Lai-kwan. 'China Who Makes and Fakes - A Semiotics of the Counterfeit', Theory, Culture \& Society 25.6 (2008): 117-140.

$\mathrm{Wu}$, Yiying and Jack Whalen. Portraits of Chinese Shanzhai (New York: American Sociological Association Annual Meeting 2013).

Yang, Fan. 'From Bandit Cell Phones to Branding the Nation: Three Moments of Shanzhai in WTO-era China', Positions: East Asia Cultures Critique 24.3 (2016): 589-619.

—. 'China's "Fake” Apple Store: Branded Space, Intellectual Property and the Global Culture Industry', Theory, Culture \& Society 31.4 (2014): 71-96. 


\section{About the Author}

Stefan Landsberger is Associate Professor at the Department of China Studies and has been part of Leiden University for over thirty years, holding various positions. From 2005-2015, Landsberger held the Olfert Dapper Chair of Contemporary Chinese Culture at the University of Amsterdam. He specialises in contemporary China, from a social and political perspective, and is an expert on Chinese political communication and visual propaganda. 